\title{
Production and Characterization of Transformed B-Lymphocytes Expressing the Membrane Defect of Scott Syndrome
}

\author{
Hiroshi Kojima, * Debra Newton-Nash, * Harvey J. Weiss, ${ }^{\ddagger}$ Ji Zhao, * Peter J. Sims, * and Therese Wiedmer \\ ${ }^{*}$ The Blood Research Institute of The Blood Center of Southeastern Wisconsin, Milwaukee, Wisconsin 53233; and ${ }^{\ddagger}$ The Department of \\ Medicine, Division of Hematology-Oncology, St. Luke's-Roosevelt Hospital Center and Columbia University College of Physicians and \\ Surgeons, New York 10019
}

\begin{abstract}
Scott syndrome is a bleeding disorder associated with an isolated defect in expression of membrane coagulant activity by stimulated platelets. This defect represents a decrease in platelet membrane binding sites for coagulation factors $\mathrm{Va}$ and VIIIa, reflecting diminished surface exposure of phosphatidylserine (PS). To gain insight into the cellular and genetic basis for this disorder, B-lymphocytes from a patient with Scott syndrome and from normal donors were immortalized by EBV-transformation, and tested for their capacity to expose plasma membrane $\mathrm{PS}$ in response to the $\mathrm{Ca}^{2+}$ ionophore, A23187. Upon incubation with A23187, EBVlymphoblasts derived from normal donors consistently induced surface expression of PS in $>70 \%$ of all cells, as detected by membrane association of the PS-binding proteins, factor Va or annexin V. PS exposure in these cells was maximal after $5 \mathrm{~min}$, and saturated at $<100 \mu \mathrm{M}$ external free $\left[\mathrm{Ca}^{2+}\right]$. By contrast, $<30 \%$ of Scott syndrome lymphoblasts exposed PS, and saturation was not observed at $>1 \mathrm{mM}$ external free $\left[\mathrm{Ca}^{2+}\right]$. Single-cell clones derived from the Scott lymphoblasts all exhibited a diminished response to A23187 comparable with that of the parental cells, suggesting that all lymphocytes from this patient share this membrane abnormality. Hybridomas prepared by fusion of Scott lymphoblasts with the myeloma cell line UC-LUC showed responses to $\mathrm{Ca}^{2+}$ ionophore comparable to those observed for normal lymphoblasts and for hybridomas prepared by fusion of normal lymphoblasts with UC-LUC. This correction of the Scott abnormality suggests possible complementation of an aberrant gene(s) responsible for this disorder. (J. Clin. Invest. 1994. 94:2237-2244.) Key words: Epstein-Barr virus • blood coagulation • phosphatidylserines - hybridomas • calcium • cell death
\end{abstract}

\section{Introduction}

The "Scott syndrome"' refers to a bleeding disorder associated with an isolated defect in expression of membrane coagulant activity by stimulated platelets $(1,2)$. Scott platelets exhibit

Address correspondence to Dr. Therese Wiedmer, The Blood Center of Southeastern Wisconsin, 1701 West Wisconsin Avenue, Milwaukee, WI 53233. 1994.

Received for publication 14 April 1994 and in revised form 27 July

J. Clin. Invest.

(C) The American Society for Clinical Investigation, Inc.

$0021-9738 / 94 / 12 / 2237 / 08 \quad \$ 2.00$

Volume 94, December 1994, 2237-2244 diminished capacity to promote plasma clotting due to reduced expression of membrane catalytic activity for the tenase (enzyme complex of coagulation factors VIIIaIXa) and prothrombinase (enzyme complex of coagulation factors $\mathrm{VaXa}$ ) reactions $(3,4)$. This defect is now known to represent a decrease in the number of newly exposed membrane binding sites for coagulation factors Va and VIIIa by the activated platelets, reflecting diminished surface exposure of phosphatidylserine (PS ) ${ }^{1}$ and reduced shedding of coagulant plasma membrane vesicles ("microparticles") from the platelet surface $(5,6)$. Although Scott platelets are defective in PS-exposure and microparticle formation in response to either calcium ionophore, complement C5b-9, or agonists such as thrombin and collagen, these platelets exhibit normal agonist-induced secretory and aggregation responses, implying a defect that selectively affects the plasma membrane events that are required for normal expression of platelet coagulant activity (2). While it has been suggested that Scott platelets contain a deficient or defective membrane component required for the normal coagulant response, the possibility that a plasma-derived inhibitor affects the surface properties of these cells has not been excluded. The erythrocytes and resealed erythrocyte ghosts prepared from this patient have recently been found to exhibit a membrane defect that is similar to that found in the platelets (7).

The mechanism by which platelet activation initiates movement of phosphatidylserine from inner-to-outer leaflets of the plasma membrane and initiates plasma membrane vesiculation remains unresolved. This response has been shown to depend upon an influx of $\mathrm{Ca}^{2+}$ across the platelet plasma membrane, and is most prominent for those agonists that cause large increases in cytosolic $\left[\mathrm{Ca}^{2+}\right](8-11)$. A similar dependence on $\mathrm{Ca}^{2+}$ is also observed for PS-exposure and expression of coagulant membrane surface by calcium ionophore-treated as well as irreversibly sickled erythrocytes (12-14). The activity of several intracellular enzymes, including calmodulin-dependent kinases, calpains, transglutaminase, and phospholipase $\mathrm{A}_{2}$, are known to be regulated by the level of cytosolic $\mathrm{Ca}^{2+}$, and inhibitors of one or more of these enzymes have been reported to affect expression of platelet coagulant activity, although direct causal relationships between enzyme activity and expression of coagulant activity remains unresolved (12, 15-19). Recently, it has been reported that $\mathrm{Ca}^{2+}$-induced transbilayer movement of PS depends on the membrane concentration of phosphatidylinositol 4,5-bisphosphate (20), suggesting direct interaction of this ion with lipid. Nevertheless, biochemical analyses of Scott platelets and erythrocytes have to date failed to reveal a compositional defect of lipid or protein that might account for the

1. Abbreviations used in this paper: AET, 2-aminoethylisothiouronium bromide; PS, phosphatidylserine; SRBC, sheep red blood cells. 
impaired responsiveness of these cells to elevated intracellular $\mathrm{Ca}^{2+}(2)$.

The observation that the plasma membrane defect observed for Scott platelets is also shared by erythrocytes and potentially other hematologic cells suggested the cellular defect might also be identified in a nucleated cell line that could be propagated through in vitro cell culture for genetic analysis. In this paper we describe cellular cloning and characterization of EBV-transformed B-lymphoblasts expressing the Scott syndrome phenotype.

\section{Methods}

Materials. BSA, RPMI 1640, L-glutamine, sodium pyruvate, 2-aminoethylisothiouronium bromide (AET), and $0.4 \%$ trypan blue solution were purchased from Sigma Chemical Co. (St. Louis, MO); HAT and HT media were from GIBCO BRL (Gaithersburg, MD); polyethylene glycol 1,500 was from Boehringer Mannheim (Indianapolis, IN); FCS was from Biocell (Dominguez, CA); lymphocyte separation medium (Ficoll) was from Organon Teknika (Durham, NC); B95-8 EpsteinBarr virus $\left(2.5 \times 10^{8}\right.$ transforming $\left.\mathrm{U} / \mathrm{ml}\right)$ was from Tampa Bay Research Institute (St. Petersburg, FL); ISOTON was from Curtin-Matheson Scientific Inc. (Houston, TX); calcium ionophore, A23187, and hygromycin B were from Calbiochem Corp. (La Jolla, CA). Bovine factor Va was from Haematologic Technologies, Inc. (Essex Junction, VT); and FITC on Celite and propidium iodide were from Molecular Probes (Eugene, OR). Murine monoclonal antibody, V237, specific for the light chain of human factor Va was a generous gift from Dr. Charles T. Esmon (Oklahoma Medical Research Foundation, Oklahoma City, $\mathrm{OK}$ ) and has been described previously (21), and the human myeloma cell line UC-LUC (22) was a gift from Dr. Paula Kavathas (Yale University, New Haven, CT). Human annexin $\mathrm{V}$ was purified from human placenta according to methods described by Funakoshi et al. (23). All other chemicals were of reagent or analytical grade.

Solutions. Sodium MOPS: $10 \mathrm{mM}$ Mops, $150 \mathrm{mM} \mathrm{NaCl}, 0.02 \%$ sodium azide, pH 7.4. PBS: $137 \mathrm{mM} \mathrm{NaCl}, 2.7 \mathrm{mM} \mathrm{KCl}, 8.1 \mathrm{mM}$ $\mathrm{Na}_{2} \mathrm{HPO}$, $1.5 \mathrm{mM} \mathrm{KH}_{2} \mathrm{PO}_{4}$, pH 7.4. Standard culture medium: RPMI 1640 supplemented with $15 \%$ heat inactivated FCS, 2 mM L-glutamine, and $1 \mathrm{mM}$ sodium pyruvate.

Fluorescence labeling of proteins. Annexin V and antibody V237 were conjugated with FITC at $\mathrm{pH}$ 9.0. The protein to be labeled was dialyzed against sodium MOPS and $\mathrm{pH}$ was adjusted to 9.0 by adding $1 / 10$ th volume of $1 \mathrm{M}$ sodium carbonate, $\mathrm{pH} 9.0$. To $0.2-0.5 \mathrm{mg}$ of the protein $(200-500 \mu \mathrm{g} / \mathrm{ml}), 1-2 \mathrm{mg}$ of FITC on Celite was delivered with rapid mixing. After incubation at room temperature for 30-60 min, the reaction was stopped by adding $1 / 10$ th volume of $1 \mathrm{M}\left(\mathrm{NH}_{4}\right)_{2} \mathrm{CO}_{3}$, $\mathrm{pH}$ 7.0. Free dye was removed by gel filtration on Sephadex G-25 (PD10, Pharmacia Biotech Inc., Piscataway, NJ), followed by exhaustive dialysis against sodium MOPS (V237) or sodium MOPS containing 0.1 mM EDTA (annexin V) in the presence of activated charcoal.

Preparation of AET-treated sheep red blood cells. SRBC were washed twice with $\mathrm{HBSS}\left(1,000 \mathrm{~g}, 10 \mathrm{~min}\right.$, at $\left.18-20^{\circ} \mathrm{C}\right)$, and incubated at $20 \%$ hematocrit in a solution of $140 \mathrm{mM} \mathrm{AET}, \mathrm{pH} 9.0$, at $37^{\circ} \mathrm{C}$ for $20 \mathrm{~min}$. The AET-treated SRBC were washed twice with PBS, and then suspended to $4 \%$ hematocrit.

$E B V$-transformed lymphoblasts. EBV-transformed B lymphoblasts were established from a patient with Scott syndrome and from nine normal donors. Briefly, PBMC were separated by Ficoll centrifugation $\left(500 \mathrm{~g}, 30 \mathrm{~min}\right.$, at $\left.17^{\circ} \mathrm{C}\right)$. Separated mononuclear cells were washed twice with serum-free RPMI 1640 , and suspended in the standard medium at a concentration of $1 \times 10^{7} / \mathrm{ml}$. To $2 \mathrm{ml}$ of PBMC, $2 \mathrm{ml}$ of heat-inactivated FCS and $2 \mathrm{ml}$ of AET-treated SRBC (4\% hematocrit) were added. After centrifugation at $200 \mathrm{~g}$ for $5 \mathrm{~min}$ at $4^{\circ} \mathrm{C}$, cells were incubated on ice for $60 \mathrm{~min}$, and then gently suspended. The cells were layered on Ficoll, centrifuged $\left(900 \mathrm{~g}, 35 \mathrm{~min}\right.$, at $\left.4^{\circ} \mathrm{C}\right)$, and the cells in the interface layer were collected, washed with PBS twice, and sus- pended at $2.5 \times 10^{6} / \mathrm{ml}$ in serum-free RPMI. The T cell-depleted lymphocytes were transformed by addition of B95-8 EBV transforming virus at a final concentration of 1 transforming $\mathrm{U} /$ cell, and incubated for $2 \mathrm{~h}$ at $37^{\circ} \mathrm{C}$ in humidified $5 \% \mathrm{CO}_{2}$ with occasional agitation. The cells were recovered by centrifugation, suspended in standard culture medium at $1.25 \times 10^{6} / \mathrm{ml}$, and plated in 96-well plates $(200 \mu \mathrm{l} / \mathrm{well})$. After $20-40 \mathrm{~d}$ of culture, growing cells were harvested and expanded. The EBV-transformed B lymphoblasts were cultured at $37^{\circ} \mathrm{C}$ in humidified $5 \% \mathrm{CO}_{2}$ in standard culture medium. All transformed cell lines were stabilized in culture for two months prior to assay. Three independent transformations of Scott syndrome lymphocytes performed with blood samples obtained from this patient (and matched controls) on separate occasions yielded indistinguishable results.

Cloning of EBV-transformed B lymphoblasts. Cloning was performed by limiting dilution in 96-well plates, with a feeder layer of irradiated human PBMC. Briefly, PBMC from a normal donor were separated by Ficoll centrifugation $\left(500 \mathrm{~g}, 30 \mathrm{~min}\right.$, at $\left.17^{\circ} \mathrm{C}\right)$. Separated PBMC were washed twice with PBS, resuspended in the standard culture medium, and then irradiated with 3,000 rad. Irradiated PBMC were transferred to each well of 96-well microtiter plates (Falcon Labware, Oxnard, CA ) at a cell concentration of $1 \times 10^{5} / \mathrm{ml}(100 \mu \mathrm{l} /$ well $)$. After culturing the feeder cells for $2-10 \mathrm{~d}$, feeder cells were aspirated, and $100 \mu \mathrm{l}$ of the EBV-transformed lymphoblasts were plated in each well (0.3-2.0 cells/well). Approximately half of the medium was changed every 4-7 d. After 2-4 wk of the culture, plates were observed by microscopy for viable clones. Selected clones were expanded in 24well plates (Falcon Labware), and this procedure was repeated.

Cell fusion. Human B cell hybridoma were prepared by fusion of EBV-transformed lymphoblasts with the hygromycin B-resistant, hypoxanthine guanine phosphoribosyl transferase (HGPRT)-deficient human myeloma cell line, UC-LUC (22). UC-LUC cells $\left(2 \times 10^{7}\right.$ cells $)$ and EBV-transformed lymphoblasts $\left(4 \times 10^{7}\right.$ cells $)$ were washed twice with serum-free RPMI 1640, and mixed in $50 \mathrm{ml}$ conical tubes. The cells were centrifuged at $200 \mathrm{~g}$ for $5 \mathrm{~min}$. After aspirating the supernatant completely, fusion was performed by resuspending the cells in $1 \mathrm{ml}$ of $50 \%$ PEG 1,500 at $37^{\circ} \mathrm{C}$, added drop-wise over $1 \mathrm{~min}$. After gentle mixing for an additional one minute, the sample was immediately diluted by slow drop-wise addition of serum-free RPMI 1640 at $37^{\circ} \mathrm{C}$. The cells were centrifuged at $200 \mathrm{~g}$ for $5 \mathrm{~min}$, resuspended in the standard culture medium supplemented with HAT and $400 \mu \mathrm{g} / \mathrm{ml}$ of hygromycin B, and then plated at a cell concentration of $1 \times 10^{5} /$ well in 96-well microtiter plates (200 $\mu \mathrm{l} /$ well). Approximately half of the medium was changed every $4 \mathrm{~d}$. After $2 \mathrm{wk}$ of culture, culture medium was changed to the standard culture medium with HT and $400 \mu \mathrm{g} / \mathrm{ml}$ of hygromycin B, and then after $3 \mathrm{wk}$, to the standard culture medium with $400 \mu \mathrm{g} / \mathrm{ml}$ of hygromycin B. Hybridomas were expanded in 24-well plates or T-25 flasks for assay.

Assay of PS exposure by flow cytometry. PS exposure on the B lymphoblast surface was detected by the specific binding of FITCconjugated annexin V (FITC-annexin V) or factor Va, the latter detected with FITC-V237 $(19,21,24)$. Lymphoblasts were washed twice with serum-free RPMI 1640 , and suspended at $37^{\circ} \mathrm{C}$, in RPMI 1640 supplemented with $0.1 \% \mathrm{BSA}$ and $1 \mathrm{mM} \mathrm{CaCl}$ (or, as otherwise indicated) at a concentration of $2.5 \times 10^{5} \mathrm{cells} / \mathrm{ml}$. At time $=0$, A23187 $(1 \mu \mathrm{M}$ final concentration) was added from $0.5 \mathrm{mM}$ stock solution in DMSO. In all experiments, identically treated cells receiving DMSO without ionophore served as untreated controls. At times indicated in figure legends, the reaction was stopped by addition of $3 \mathrm{mM}$ EDTA. $50 \mu \mathrm{l}$ of the cells were transferred to tubes containing $5 \mu \mathrm{l}$ of bovine factor $\mathrm{Va}$ (final concentration, $5 \mu \mathrm{g} / \mathrm{ml}$ ), and incubated at room temperature for $15 \mathrm{~min}$, after which cells were stained with FITC conjugated V237 $(5 \mu \mathrm{g} / \mathrm{ml})$ for an additional $15 \mathrm{~min}$. Samples were then diluted by adding $250 \mu \mathrm{l}$ ISOTON, and the binding of FITC-V237 was assayed by flow cytometry (FACScan ${ }^{\circledR}$; Becton Dickinson, San Jose, CA) immediately after dilution. The data of 2,000 cells were acquired by using a forward angle light scatter trigger. For measurement of annexin $\mathrm{V}$ binding, after the treatment with $\mathrm{Ca}^{2+}$ and $1 \mu \mathrm{M} \mathrm{A} 23187,50 \mu \mathrm{l}$ of the cell suspension was transferred to tubes containing $5 \mu \mathrm{l}$ of FITC-annexin 
$\mathrm{V}$ (final concentration, $3 \mu \mathrm{g} / \mathrm{ml}$ ). After incubation for $15 \mathrm{~min}$ at room temperature, the samples were diluted with $250 \mu \mathrm{l}$ of ISOTON for flow cytometry. Data analysis was performed using the Lysis II software (Becton Dickinson). To quantitate the number of calcium ionophore responsive cells in each sample, a FITC fluorescence threshold was set so as to include $98 \%$ of the non-activated cells (representing background binding of factor $\mathrm{Va}$ or annexin $\mathrm{V}$ ) in each untreated sample. The number of cells that exposed surface PS in response to treatment with A23187 (defined as calcium responsive cells) was then determined from the ratio of FITC-negative cells in the A23187-treated versus untreated samples, according to (see Fig. 1):

percent calcium responsive cells

$$
=100 \times\left[1-\frac{\text { percent FITC-negative cells }(\mathrm{A} 23187)}{\text { percent FITC-negative cells }(\text { untreated })}\right]
$$

$\mathrm{Ca}^{2+}$ dependence of PS exposure. To deduce the relationship between extracellular ionized $\mathrm{Ca}^{2+}$ and A23187-induced PS exposure, lymphoblasts $\left(2.5 \times 10^{5}\right.$ cells $\left./ \mathrm{ml}\right)$ were washed and suspended in RPMI 1640, 0.1\% BSA, $20 \mathrm{mM}$ Hepes, $1.2 \mathrm{mM}$ EGTA, with concentrations of $\mathrm{CaCl}_{2}$ between 0 and $4 \mathrm{mM}$, and then incubated with 0 or $1.0 \mu \mathrm{M}$ A23187 for $10 \mathrm{~min}$ at $37^{\circ} \mathrm{C}$. The reaction was stopped by addition of EDTA, and calcium responsive cells determined from the exposure of factor $\mathrm{Va}$ binding sites, measured by flow cytometry. Ionized $\mathrm{Ca}^{2+}$ under each condition was calculated using FreeCal version 4.0 software (generously provided by Dr. Lawrence F. Brass, University of Pennsylvania, Philadelphia, PA).

Propidium iodide staining. EBV-transformed lymphoblasts were washed twice with serum-free RPMI 1640 and suspended $\left(2 \times 10^{6}\right.$ cells/m) in RPMI 1640, 0.1\% BSA, $1 \mathrm{mM} \mathrm{CaCl}_{2}$. Activation was performed by addition of $1 \mu \mathrm{M} \mathrm{A23187}$. After $40 \mathrm{~min}$ incubation at $37^{\circ} \mathrm{C}$, cells were stained ( $3 \mathrm{~min}$, room temperature) by addition of $5 \mu \mathrm{g} / \mathrm{ml}$ propidium iodide. After 10-fold dilution in ISOTON, the percentage of propidium-stained cells were analyzed by flow cytometry.

Trypan blue staining. A23187-treated and untreated cells were stained by addition of trypan blue (final concentration $0.2 \%$ ) and immediately examined by microscopy. The percentage of cells incorporating stain was determined in independent assays of duplicate samples.

\section{Results}

$E B V$-transformed $B$ lymphoblasts expressing membrane defect of Scott syndrome. To clarify whether the defect in $\mathrm{Ca}^{2+}$-inducible PS exposure that is characteristic of Scott syndrome platelets and erythrocytes reflects an inherent genetic defect that is expressed in multiple cell lineages and that propagates through cell division, EBV-transformed lymphoblasts were prepared from B-lymphocytes isolated from the blood of this patient (primary lymphoblast cell line, designated Scott-O). EBVtransformed lymphoblasts prepared from nine normal donors served as controls ( see Methods). After at least $8 \mathrm{wk}$ of stabilization in culture, the EBV-transformed cell lines were further expanded and analyzed for their capacity to expose PS on the surface of the plasma membrane upon treatment with the calcium ionophore, A23187. As described in Methods, PS exposure was detected either by the exposure of plasma membrane binding sites for factor Va (Fig. 1), or, by the binding of FITClabeled annexin $\mathrm{V}$ (data not shown). As illustrated by these data, incubation with A23187 in the presence of $1.4 \mathrm{mM}$ external $\left[\mathrm{Ca}^{2+}\right]$ induced new factor $\mathrm{Va}$ binding sites on virtually all of the lymphoblasts derived from normal donor lymphocytes. Similar results were obtained using FITC-labeled annexin V to probe surface-exposed PS (not shown). This ionophore-mediated exposure of membrane binding sites for these PS-binding
Scott-0 Normal Control
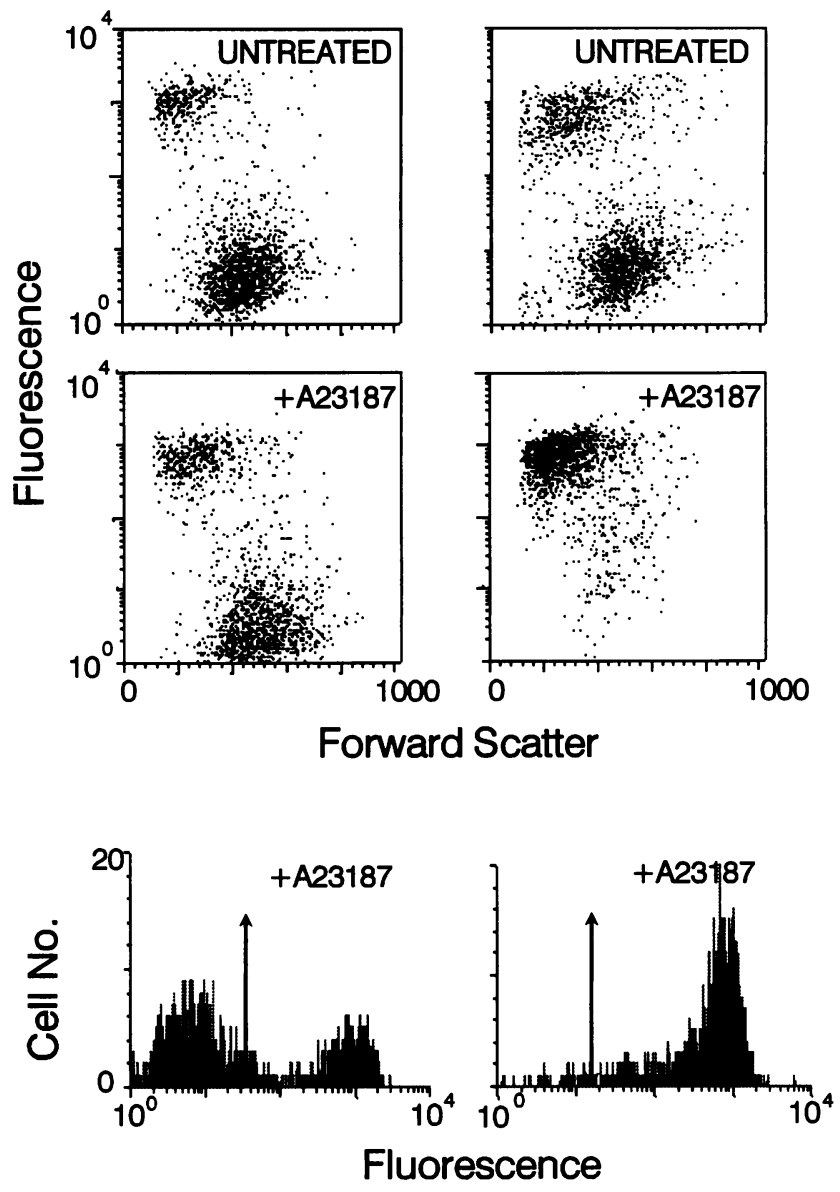

Figure 1. PS exposure in Scott-O and normal control lymphoblasts as detected by binding of factor Va. Washed lymphoblasts (Scott-O and W9), suspended at $2.5 \times 10^{5}$ cells $/ \mathrm{ml}$ in RPMI 1640 with $0.1 \%$ BSA, $1 \mathrm{mM} \mathrm{CaCl}_{2}$, were treated with $1 \mu \mathrm{M} \mathrm{A} 23187$. After incubating $15 \mathrm{~min}$ at $37^{\circ} \mathrm{C}, 3 \mathrm{mM}$ EDTA was added and cells were stained by addition of factor Va and antibody FITC-V237, as described in Methods. Dot plots denote forward angle light scatter (linear scale; abscissa) versus FITC fluorescence intensity (logarithmic scale; ordinate). Also shown are histograms of FITC-fluorescence (logarithmic scale; abscissa) for the ionophore-treated samples. Arrows in the histograms indicate the threshold of positivity used to determine the relative number of calcium responsive cells under each condition (see Methods). Data of a single experiment, representative of results obtained in more than 20 independent experiments, using Scott-O and nine separate normal controls.

proteins has been shown in other cells to reflect an intracellular $\mathrm{Ca}^{2+}$-initiated transbilayer migration of PS from inner-to-outer leaflets of the plasma membrane $(21,24,25)$. In addition to exposing membrane binding sites for factor $\mathrm{Va}$ and annexin $\mathrm{V}$, the ionophore-treated lymphoblasts showed a distinct shift in forward light scatter, reflecting change in refractility and reduced cell size. By contrast to the results obtained with normal donor lymphoblasts, the Scott-O lymphoblasts were distinctly resistant to this treatment, with only $20-30 \%$ of all cells converting to the activated phenotype (surface PS-positive and reduced size) upon incubation with the calcium ionophore (see also Fig. 2). This distinct difference in the response to $\mathrm{Ca}^{2+}$ ionophore of the Scott-O lymphoblasts versus normal-donor 


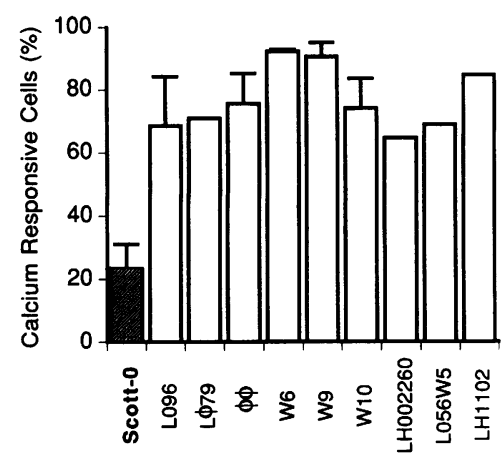

Figure 2. Percentage of calcium responsive cells detected in Scott-O and normal control lymphoblasts. A23187induced PS exposure in Scott-O lymphoblasts (hatched bar) and lymphoblasts prepared from nine normal controls (open bars) was determined from the exposure of new membrane binding sites for factor

$\mathrm{Va}$, as detected by flow cytometry (see Fig. 1). The number of calciumplus-ionophore responsive cells in each sample (expressed as the percentage of all cells) was determined as described in Methods. Data plotted represent mean values obtained in at least 20 independent experiments using Scott-O, and at least three independent experiments in the case of the normal control cell lines L096, $\phi \phi$, W6, W9, and W10. Results for cell lines L $\phi 79$, LH002260, L056W5, and LH1102 were obtained in a single experiment. Error bars denote SD.

cell lines was stably expressed in these cells during continuous culture for periods in excess of 6 mo. Essentially the same results were obtained in experiments performed with Scott-O cells (and control lymphoblasts) prepared in independent EBVtransformations of peripheral blood B-cells isolated from this patient on three separate occasions over a period of $11 \mathrm{mo}$ (data not shown). In all cell lines, a small and variable number $(<20 \%)$ of surface PS-positive cells was also detected in the untreated samples (see Fig. 1), which is likely to reflect membrane damage arising during the multiple washing procedures required for these measurements. No consistent difference in this background of initially PS-positive cells was observed between Scott-O lymphoblasts and the lymphoblasts prepared from normal donors, and the PS-positive cells in the untreated samples were excluded from analysis (see below).

Comparison of $\mathrm{Ca}^{2+}$ response of Scott-O and lymphoblasts from normal donors. To quantitatively compare the number of $\mathrm{Ca}^{2+}$-responsive and nonresponsive cells in each cell line, we analyzed the A23187-induced conversion of initially surface PS-negative to surface-PS positive cells in each population. As summarized by the data of Fig. 2, in the case of lymphoblasts derived from normal donors, exposure to $\mathrm{Ca}^{2+}$ plus $\mathrm{A} 23187$ under the conditions of these experiments converted 70-90\% of all cells to the PS-positive (i.e., factor Va-binding) phenotype. By contrast, only $20-30 \%$ of the Scott-O lymphoblasts expressed factor $\mathrm{Va}$ binding sites under these conditions.

Dependence on external $\left[\mathrm{Ca}^{2+}\right]$. To determine whether the diminished response of the Scott-O cell line detected under the conditions of Fig. 1 reflected either altered kinetics or decreased sensitivity to $\left[\mathrm{Ca}^{2+}\right]$ per se, the time-dependent and $\left[\mathrm{Ca}^{2+}\right]$ dependent responses of Scott-O cells to A23187 were compared with normal donor lymphoblasts (Fig. 3). As illustrated by these data, the response of the normal donor lymphoblasts was nearly-maximally expressed within $5 \mathrm{~min}$ after addition of ionophore, while the ionophore-induced response of Scott-O cells failed to reach the levels of normal controls, even after $30 \mathrm{~min}$ incubation (Fig. $3 \mathrm{~A}$ ). The apparent half-maximal induction of the PS-exposed phenotype in A23187-treated lymphoblasts derived from normal donors was observed at approximately 18 $\mu \mathrm{M}$ extracellular free $\left[\mathrm{Ca}^{2+}\right]$, and saturated by $100 \mu \mathrm{M} \mathrm{Ca}^{2+}$ (Fig. $3 B$ ). By comparison, in A23187-treated Scott-O lymphoblasts, saturation of this response was not observed at $>1 \mathrm{mM}$ external free $\left[\mathrm{Ca}^{2+}\right]$, the apparent half-maximal response requiring $>45 \mu \mathrm{M} \mathrm{Ca}^{2+}$.

Relationship to cell viability. In addition to nuclear degradation, the induction of programmed cell death in lymphocytes and other cells is known to be accompanied by increased cytosolic $\left[\mathrm{Ca}^{2+}\right]$, and consequent changes in the transmembrane distribution of plasma membrane phospholipids, with ultimate loss of plasma membrane integrity. Furthermore, treatment of B-lymphocytes with calcium ionophore has been shown to directly induce many of the cellular changes associated with cellular apoptosis $(26,27)$. It was therefore of interest to determine whether the apparent resistance of Scott-O cells to $\mathrm{Ca}^{2+}$ ionophore-induced exposure of PS is also reflected by increased resistance of these cells to the loss of plasma membrane integrity that normally accompanies a sustained elevation of cytosolic $\left[\mathrm{Ca}^{2+}\right]$. We therefore compared the plasma membrane integrity
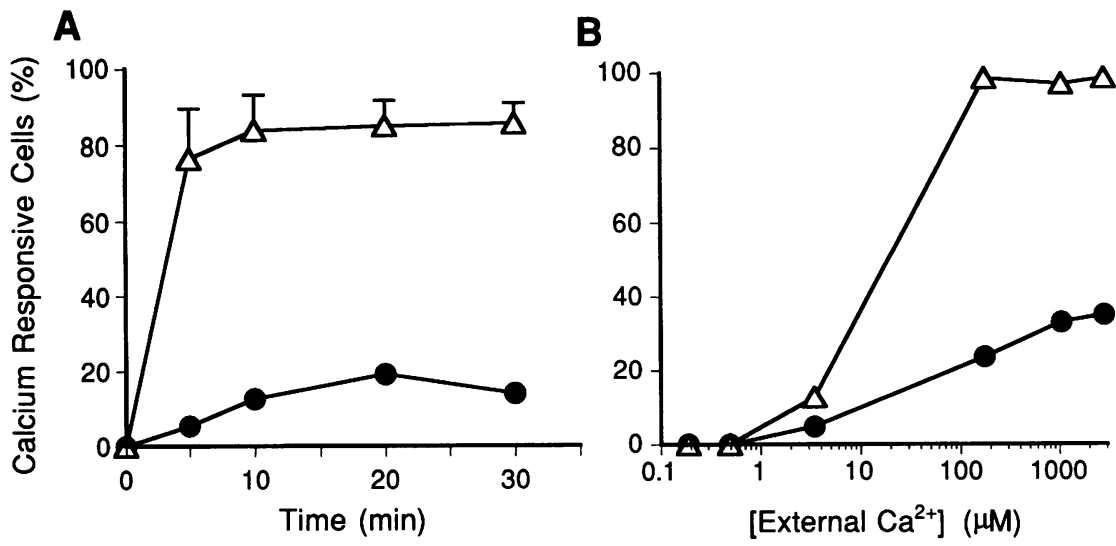

Figure 3. Kinetics of PS exposure and dependence on external $\left[\mathrm{Ca}^{2+}\right] .(A)$ Scott-O $(\bullet)$ and three normal control lymphoblasts (W6, W9, and W10; $\Delta$ ) were incubated with $1 \mu \mathrm{M} \mathrm{A23187}$ under conditions described in Fig. 1. Cells identically exposed to DMSO but not ionophore served as untreated cells. At the indicated times (abscissa) $50 \mu \mathrm{l}$ of each suspension was transferred to tubes containing $1 \mu \mathrm{l}$ of $150 \mathrm{mM}$ EDTA, and PS exposure was determined from the exposure of factor $\mathrm{Va}$ binding sites. Calcium responsive cells (ordinate) at each time was calculated as described in Methods. Error bars denote mean + SD for three separate normal cell lines. Data of single experiment, representative of results obtained in three independent experiments. $(B)$ Scott-O (•) and normal control lymphoblasts

(W9; $\triangle$ ) were suspended in RPMI 1640, $0.1 \%$ BSA, $20 \mathrm{mM}$ Hepes, $1.2 \mathrm{mM}$ EGTA and various concentrations of $\mathrm{CaCl}_{2}$ to obtain concentrations of ionized $\mathrm{Ca}^{2+}$ denoted on abscissa (logarithmic scale; see Methods). PS exposure was induced by incubation for $10 \mathrm{~min}$ at $37^{\circ} \mathrm{C}$ with $1 \mu \mathrm{M}$ A23187. Cells identically exposed to DMSO but not ionophore served as untreated cells. After addition of EDTA, PS exposure was detected by flow cytometry, using factor Va (see Fig. 1). Calcium responsive cells (ordinate) at each $\left[\mathrm{Ca}^{2+}\right]$ was calculated as described in Methods. Data of single experiment, representative of three similar experiments. 
Table I. Analysis of Propidium Iodide and Trypan Blue Staining

\begin{tabular}{|c|c|c|c|c|}
\hline & \multicolumn{2}{|c|}{ Propidium iodide } & \multicolumn{2}{|c|}{ Trypan blue } \\
\hline & Scott-0 & Control & Scott-0 & Control \\
\hline \multicolumn{5}{|c|}{ Percent positively stained cells } \\
\hline Untreated & 17.7 & $16.2 \pm 9.1$ & 10.0 & $5.9 \pm 4.7$ \\
\hline$+\mathrm{A} 23187$ & 33.7 & $64.8 \pm 5.3$ & 7.6 & $87.8 \pm 2.6$ \\
\hline
\end{tabular}

Scott- 0 and three control lymphoblasts were incubated with $1 \mu \mathrm{M}$ A23187 in the presence of $1.4 \mathrm{mM} \mathrm{CaCl}_{2}$, and then stained with either propidium iodide or trypan blue (see Methods). Results are expressed as the percentage of cells that incorporate dye. Untreated cells refer to identical-matched pair lymphoblasts (Scott-0 or control) exposed to DMSO, but not A23187. Data for controls represent mean \pm SD determined for three separate control cell lines.

of A23187-treated Scott-O versus normal lymphoblasts by staining with trypan blue and propidium iodide (Table I), under conditions that resulted in conversion of approximately $20 \%$ (Scott-O) versus $>90 \%$ (normal controls) of the cells to the PS-positive phenotype, evaluated by factor Va binding ( see Fig. 1). As illustrated by these data, the marked difference in $\mathrm{Ca}^{2+}$ sensitivity of Scott-O cells versus normal controls that is observed for PS exposure was also observed with respect to cell staining by both of these markers of plasma membrane integrity.

Cloning of EBV-transformed Scott lymphoblasts. The data of Figs. 1 and 2 suggest that $\sim 20-30 \%$ of the Scott-O lymphoblasts respond normally to calcium ionophore, raising the possibility that this line includes cells of mixed phenotype, reflecting both normal and abnormal sensitivities to $\mathrm{Ca}^{2+}$. Alternatively, the reduced response of Scott-O cells to treatment with A23187 might reflect a diminished probability for induced rearrangement of plasma membrane lipid at each concentration of cytosolic $\mathrm{Ca}^{2+}$, that is shared by all cells in the population. This latter possibility was suggested by the observation that PS exposure in A23187-treated Scott-O cells appears shifted to elevated $\left[\mathrm{Ca}^{2+}\right]$ versus A23187-treated normal lymphoblasts (Fig. 3), implying that a diminished sensitivity to internal $\mathrm{Ca}^{2+}$ is exhibited by the $20-30 \%$ of Scott-O cells that do respond to ionophore, as well as the $70-80 \%$ of the cells that remain quiescent under the conditions of these experiments. To address this question, we undertook to analyze the $\mathrm{Ca}^{2+}$-response of single-cell clonal lines derived from the Scott-O lymphoblasts. In these experiments, seven independent clonal cell lines derived from Scott-O were analyzed for A23187-induced factor Va binding, and compared to the response of the parental (ScottO) cell line. The responses of the daughter clones appeared to be normally distributed with respect to that of the parental Scott$\mathrm{O}$, and all showed markedly diminished responses to A23187 when compared with lymphoblasts derived from normal donors (data not shown). To confirm that the initial cloning resulted in single-cell derived progeny, two of the Scott-O-derived clones, (3E8 and 2C10) were further cloned, and five secondary clones from each were analyzed. All of these secondary clones showed abnormal response to calcium ionophore, characteristic of the Scott-O lymphoblasts (data not shown).

Correction of the abnormal phenotype by somatic cell hybridization. Propagation of the abnormal phenotype of Scott-O lymphoblasts through multiple cell divisions implied that the basis for this disorder is a gene mutation affecting $\mathrm{Ca}^{2+}$-medi-

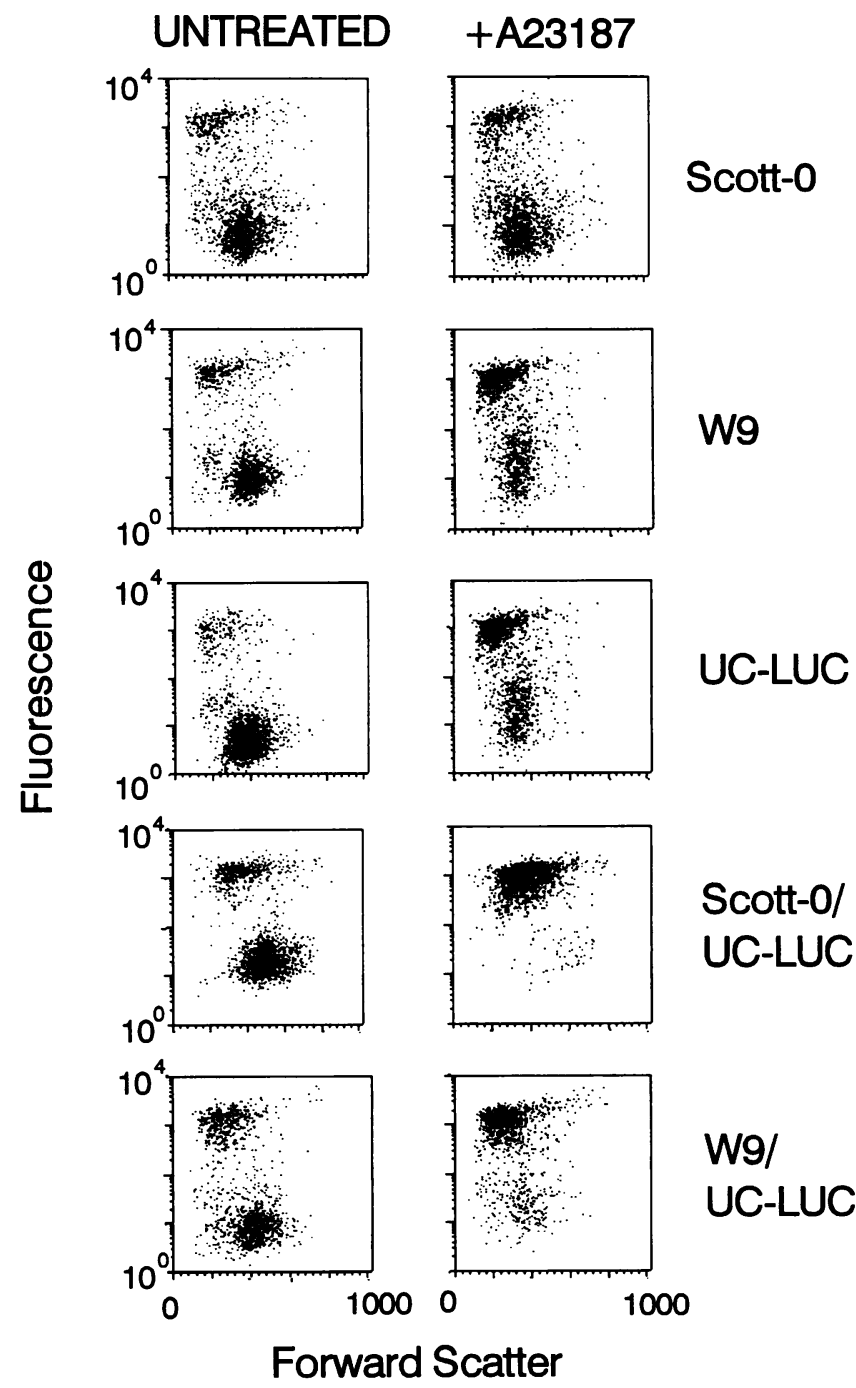

Figure 4. Calcium ionophore-induced PS exposure in B-cell hybridomas derived from Scott lymphoblasts. Hybridomas prepared by fusion of Scott-O with the myeloma cell line, UC-LUC (Scott-O/UC-LUC) were analyzed for A23187-induced PS exposure under conditions described for Fig. 1. Comparison was made to the parental lymphoblast cell line Scott-O, the normal control lymphoblast cell line W9, the myeloma cell line UC-LUC, and the hybridoma prepared by fusion of W9 with UCLUC (W 9/UC-LUC). For each cell line, left hand panel denotes untreated cells; right-hand panel are cells treated with $1 \mu \mathrm{M} \mathrm{A23187.} \mathrm{All}$ dot plots denote forward angle light scatter (linear scales; abscissa) and FITC-fluorescence (logarithmic scales; ordinate). Data of single experiment, representative of results obtained in $>20$ independent experiments so performed.

ated changes in the physical properties of the plasma membrane, a defect that is also presumably shared by the platelet and erythroid progenitor cells of this patient. Unresolved is whether the observed phenotype reflects a mutation that results in a loss of normal function (e.g., a membrane-associated component with diminished affinity for $\mathrm{Ca}^{2+}$ ), or, whether the phenotype of these cells reflects the over-expression of a cellular component that normally serves to stabilize the plasma membrane. To gain initial insight into the potential for genetic transfer of the Scott trait, hybridoma cell lines were prepared by fusion of the Scott-O lymphoblasts with the human myeloma cell line, UC- 

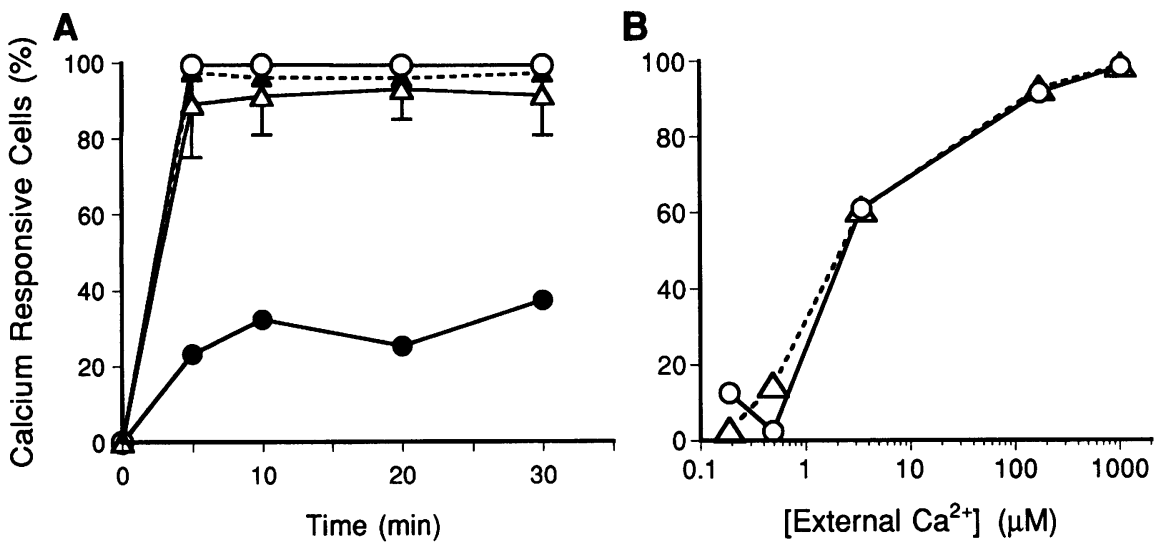

Figure 5. Kinetics of PS exposure and dependence on external $\left[\mathrm{Ca}^{2+}\right]$ in Scott and control hybridomas. $(A)$ The hybridoma cell lines Scott-O/UC-LUC (O) and W9/UC-LUC $(\triangle)$ were incubated with $1 \mu \mathrm{M}$ A23187 under conditions described in Fig. 1. Cells identically exposed to DMSO but not ionophore served as untreated cells. At the indicated times (abscissa) $50 \mu \mathrm{l}$ of each suspension was transferred to tubes containing $1 \mu \mathrm{l}$ of $150 \mathrm{mM}$ EDTA, and PS exposure was determined from the exposure of factor Va binding sites. Calcium responsive cells (ordinate) at each time was calculated as described in Methods. Comparison is made to data for the parental lymphoblast cell lines Scott-O (•)

and W9 ( $\Delta$ ). Error bars denote mean + SD obtained for three independent hybridoma cell lines. Data of single experiment, representative of results obtained in three independent experiments. $(B)$ The hybridoma cell lines Scott-O/UC-LUC $(O)$ and W9/UC-LUC $(\triangle)$ were suspended in RPMI $1640,0.1 \%$ BSA, $20 \mathrm{mM}$ Hepes, $1.2 \mathrm{mM}$ EGTA and various concentrations of $\mathrm{CaCl}_{2}$ to obtain concentrations of ionized $\mathrm{Ca}^{2+}$ denoted on abscissa (logarithmic scale; see Methods). PS exposure was induced by incubation for $10 \mathrm{~min}$ at $37^{\circ} \mathrm{C}$ with $1 \mu \mathrm{M} \mathrm{A23187}$. Cells identically exposed to DMSO but not ionophore served as untreated cells. After addition of $3 \mathrm{mM}$ EDTA, PS exposure was detected by flow cytometry, using factor Va (see Fig. 1). Calcium responsive cells (ordinate) at each $\left[\mathrm{Ca}^{2+}\right]$ was calculated as described in Methods. Data of single experiment, representative of three similar experiments.

LUC, and the resulting Scott-O/UC-LUC hybridomas evaluated for $\mathrm{Ca}^{2+}$-induced PS exposure after selection on HAT medium and propagation in culture (Figs. 4 and 5). In all experiments, comparison was made to hybridomas prepared by fusion of a normal control lymphoblast line (W9) with the UC-LUC myeloma cells (W9/UC-LUC). As illustrated by the dot plots in Fig. $4, \mathrm{Ca}^{2+}$ ionophore-induced PS exposure in the myeloma cell line UC-LUC closely approximated that seen for W9 and other EBV-lymphoblasts from normal donors, with increased factor $\mathrm{Va}$ binding observed for $>80 \%$ of the ionophore-treated cells, versus $<30 \%$ in the case of Scott-O (see Figs. 1, 2, and 4). Hybridomas generated by fusion of Scott-O with UC-LUC showed a responsiveness to ionophore comparable to that observed for hybridomas prepared by fusion of W9 (or other control lymphoblasts; not shown) to UC-LUC (compare ScottO/UC-LUC to W9/UC-LUC in Fig. 5 and Table II), suggesting a possible "dominance" of the wild-type ("high responder") phenotype that is characteristic of the lymphoblasts derived

Table II. A23187-induced PS Exposure in Scott and Control Hybridomas

\begin{tabular}{cc}
\hline & $\mathrm{Ca}^{2+}$ Responsive cells (\%) \\
\hline Parental cells & mean $\pm S D$ \\
Scott-0 & $22.4 \pm 7$ \\
W9 & $90.2 \pm 5$ \\
UC-LUC & $97.7 \pm 4$ \\
Hybridomas & \\
Scott-0/UC-LUC & $97.7 \pm 2$ \\
W9/UC-LUC & $95.1 \pm 4$ \\
\hline
\end{tabular}

PS exposure in six independent Scott-0/UC-LUC hybridomas, and 10 independent W9/UC-LUC hybridomas were assayed by methods described in Fig. 2. Data are compared with results for parental lymphoblast cell lines Scott-0 and W9, and the myeloma cell line, UC-LUC. Measurement of the calcium response of each cell line was performed in triplicate assay, expressed as mean \pm SD. from normal donor lymphocytes (see Discussion). Consistent with this interpretation, PS exposure in the ionophore-treated Scott-O/UC-LUC hybridomas showed similar dependence on time and extracellular $\left[\mathrm{Ca}^{2+}\right]$ as was observed for the ionophore-treated W9/UC-LUC hybridomas (Fig. 5), or for the normally $\mathrm{Ca}^{2+}$-responsive parental cell lines (W9 or UC-LUC).

\section{Discussion}

Previous studies of the cellular defect in Scott syndrome have provided substantial insight into how the normal expression of platelet coagulant activity depends upon an active remodeling of plasma membrane phospholipids that is initiated through increased intracellular $\mathrm{Ca}^{2+}(2,5-7)$. Nevertheless, the physical and molecular processes that are responsible for this rearrangement of the normal configuration of plasma membrane phospholipids remain unresolved. Furthermore, studies with platelets and erythrocytes obtained from this patient have failed to unequivocally distinguish whether the defects observed in this syndrome are of humoral or cellular origin, and biochemical analyses of blood obtained from this patient have to date failed to reveal a missing or aberrant component of blood plasma or of the platelet plasma membrane that might account for the observed defect in platelet coagulant response.

In this paper, we demonstrate that the coagulant nonresponder phenotype previously associated with Scott syndrome platelets and erythrocytes is expressed by all of the EBV-transformed lymphoblasts derived from the B-cells of this patient, and that the unique phenotype of the defective cells can be isolated by single cell cloning and propagated in culture through many generations. The continuous expression of this aberrant phenotype through in vitro culture confirms that the Scott syndrome defect represents a gene deletion or mutation that is passed to daughter cells through mitosis. Furthermore, we demonstrate by heterokaryon hybridoma fusion that the abnormal Scott phenotype can be corrected by fusion with a cell exhibiting the normal coagulant-responder phenotype, and that the normal phenotype is sustained when these hybridomas are subsequently propagated through many generations. Taken together with the 
results of previous studies, these data suggest that the cellular defect observed in Scott syndrome reflects a mutation or deletion of a gene(s) that is required for normal $\mathrm{Ca}^{2+}$-dependent transbilayer migration of PS to the plasma membrane surface, that this defect is phenotypically corrected through somatic cell fusion with wild-type (responder) cell lines reflecting possible genetic complementation, and that this defect is shared among the blood cells of lymphoid, megakaryocytic and erythroid lineages in this patient.

Previous flow cytometric analysis of the platelets in Scott syndrome suggested that the normal coagulant response to various agonists was attenuated by $\sim 60-90 \%$ (6), consistent with the estimated two-thirds reduction from normal levels of platelet-catalyzed tenase and prothrombinase activity originally reported for this patient (4). Furthermore, these studies suggested that the platelet defect might be of clonal origin, as those Scott cells that responded to agonist bound nearly equivalent amounts of factor Va per cell as did activated platelets from normal donors. These experiments, however, failed to resolve whether the attenuated coagulant response observed for Scott platelets reflects coexisting populations of "responder" and "nonresponder" cells, or alternatively, that all platelets from this patient share the same potential to express factor $\mathrm{Va}$ binding sites upon activation, but that the probability of the coagulant response upon elevation of intracellular $\mathrm{Ca}^{2+}$ is approximately one-third that of normal. The results of single cell cloning suggest that all of the lymphoblasts derived from this patient share the characteristic phenotype exhibited by other blood cells in this disorder, and that this phenotype reflects a diminished probability in all blood cells for induction of PS-exposure at elevated cytosolic $\left[\mathrm{Ca}^{2+}\right]$. Nevertheless, it should be noted that we cannot exclude the possibility that our failure to derive clones with a normal (wild-type) $\mathrm{Ca}^{2+}$ response from the Scott-O cell line reflects a pre-selection of only the aberrant cells, either at the stage of EBV-transformation of blood lymphocytes, or, by virtue of a different viability of the cells through single-cell cloning and subsequent expansion.

The mode of inheritance of the Scott defect is unknown. Nevertheless, the apparent correction of the Scott syndrome defect in all hybridomas derived from fusion of Scott-O with the UC-LUC myeloma cell line (Table II and Figs. 4 and 5) suggests the possibility for genetic complementation of the membrane defect of the Scott syndrome by expression of the wild type $\left(\mathrm{Ca}^{2+}\right.$-responsive $)$ genome. Although these experiments do not exclude the possibility that the Scott phenotype reflects the over-expression of an inhibitor of the $\mathrm{Ca}^{2+}$-response in Scott blood cells, the expression of a normal phenotype by all Scott-O/UC-LUC derived hybridomas suggests that the Scott mutation is a recessive loss-of-function mutation that can be corrected through co-expression of the wild-type gene. In addition to providing a stable cellular source for future study of the genetic basis for the cellular defect in Scott syndrome, isolation of clonal cell lines exhibiting a selective defect in $\mathrm{Ca}^{2+}$-initiated PS exposure potentially provides a new tool to undertake identification of those gene(s) responsible for maintaining and collapsing the normal asymmetric distribution of plasma membrane phospholipids.

\section{Acknowledgments}

The authors gratefully acknowledge the assistance of the patient whose generous cooperation made this study possible. We wish to acknowledge the superb technical assistance of Susan O. Freiburger, Lilin $\mathrm{Li}$, and Randal P. Orchekowski. The comments and suggestions of Dr. Alfred L. M. Bothwell (Yale University) and Sanford J. Shattil (University of Pennsylvania) are also gratefully acknowledged. We wish to thank Dr. Charles T. Esmon (Oklahoma Medical Research Foundation) for supplying antibody V237 and Dr. Paula B. Kavathas (Yale University) for supplying the myeloma cell line UC-LUC.

This research was supported by grants HL-36946 (P. J. Sims), HL40796 (T. Wiedmer), and HL-27346 (H. J. Weiss) from the Heart, Lung, and Blood Institute, National Institutes of Health.

\section{References}

1. Weiss, H. J., W. J. Vicic, B. A. Lages, and J. Rogers. 1979. Isolated deficiency of platelet procoagulant activity. Am. J. Med. 67:206-213.

2. Weiss, H. J. 1994. Scott Syndrome-a disorder of platelet coagulant activity (PCA). Semin. Hematol. 31:312-319.

3. Miletich, J. P., W. H. Kane, S. L. Hofmann, N. Stanford, and P. W. Majerus. 1979. Deficiency of Factor- $X_{a}-$ Factor $V_{a}$ binding sites on the platelets of a patient with a bleeding disorder. Blood 54:1015-1022.

4. Rosing, J., E. M. Bevers, P. Comfurius, H. C. Hemker, G. van Dieijen, H. J. Weiss, and R. F. Zwaal. 1985. Impaired Factor X and prothrombin activation associated with decreased phospholipid exposure in platelets from a patient with a bleeding disorder. Blood. 65:1557-1561.

5. Ahmad, S. S., R. Rawala-Sheikh, B. Ashby, and P. N. Walsh. 1989. Platelet receptor-mediated factor $\mathrm{X}$ activation by factor IXa: high-affinity factor IXa receptors induced by factor VIII are deficient on platelets in Scott syndrome. J. Clin. Invest. 84:824-828.

6. Sims, P. J., T. Wiedmer, C. T. Esmon, H. J. Weiss, and S. J. Shattil. 1989. Assembly of the platelet prothrombinase complex is linked to vesiculation of the platelet plasma membrane. Studies in Scott syndrome: an isolated defect in platelet procoagulant activity. J. Biol. Chem. 264:17049-17057.

7. Bevers, E. M., T. Wiedmer, P. Comfurius, S. J. Shattil, H. J. Weiss, R. F Zwaal, and P. J. Sims. 1992. Defective $\mathrm{Ca}^{2+}$-induced microvesiculation and deficient expression of procoagulant activity in erythrocytes from a patient with a bleeding disorder: a study of the red blood cells of Scott syndrome. Blood. 79:380388 .

8. Williamson, P., A. Kulick, A. Zachowski, R. A. Schlegel, and P. F. Devaux. 1992. $\mathrm{Ca}^{2+}$ induces transbilayer redistribution of all major phospholipids in human erythrocytes. Biochemistry. 31:6355-6360.

9. Basse, F., P. Gaffet, F. Rendu, and A. Bienvenue. 1993. Translocation of spin-labeled phospholipids through plasma membrane during thrombin- and ionophore A23187-induced platelet activation. Biochemistry. 32:2337-2344.

10. Chang, C.-P., J. Zhao, T. Wiedmer, and P. J. Sims. 1993. Contribution of platelet microparticle formation and granule secretion to the transmembrane migration of phosphatidylserine. J. Biol. Chem. 268:7171-7178.

11. Connor, J., K. Gillum, and A. J. Schroit. 1990. Maintenance of lipid asymmetry in red blood cells and ghosts: Effect of divalent cations and serum albumin on the transbilayer distribution of phosphatidylserine. Biochim. Biophys. Acta. 1025:82-86.

12. Comfurius, P., J. M. Senden, R. H. Tilly, A. J. Schroit, E. M. Bevers, and R. F. Zwaal. 1990. Loss of membrane phospholipid asymmetry in platelets and red cells may be associated with calcium-induced shedding of plasma membrane and inhibition of aminophospholipid translocase. Biochim. Biophys. Acta. 1026:153-160.

13. Franck, P. F., E. M. Bevers, B. H. Lubin, P. Comfurius, D. T.-Y. Chiu, J. A. F. Op den Kamp, and R. F. A. Zwaal. 1985. Uncoupling of the membrane skeleton from the lipid bilayer. The cause of accelerated phospholipid flip-flop leading to an enhanced procoagulant activity of sickled cells. J. Clin. Invest. 75:183-190.

14. Zwaal, R. F. A., E. M. Bevers, P. Comfurius, J. Rosing, R. H. Tilly, and P. F. Verhallen. 1989. Loss of membrane phospholipid asymmetry during activation of blood platelets and sickled red cells; mechanisms and physiological significance. Mol. Cell. Biochem. 91:23-31.

15. Fox, J. E. B., C. C. Reynolds, and C. D. Austin. 1990. The role of calpain in stimulus-response coupling: Evidence that calpain mediates agonist-induced expression of procoagulant activity in platelets. Blood. 76:2510-2519.

16. Bratton, D. L. 1993. Release of platelet activation factor from activated neutrophils. Transglutaminase-dependent enhancement of transbilayer movement across the plasma membrane. J. Biol. Chem. 268:3364-3373.

17. Wiedmer, T., and P. J. Sims. 1991. Participation of protein kinases in complement C5b-9-induced shedding of platelet plasma membrane vesicles. Blood. 78:2880-2886.

18. Wiedmer, T., S. J. Shattil, M. Cunningham, and P. J. Sims. 1990. Role of calcium and calpain in complement-induced vesiculation of the platelet plasma membrane and in the exposure of the platelet factor Va receptor. Biochemistry. 29:623-632. 
19. Dachary-Prigent, J., J-M. Freyssinet, J-M. Pasquet, J-C. Carron, and A. T. Nurden. 1993. Annexin V as a probe of aminophospholipid exposure and platelet membrane vesiculation: A flow cytometry study showing a role for free sulf hydryl groups. Blood. 81:2554-2565.

20. Sulpice, J-C., A. Zachowski, P. F. Devaux, and F. Giraud. 1994. Requirement for phosphatidylinositol 4,5-biphosphate in the $\mathrm{Ca}^{2+}$-induced phospholipid redistribution in the human erythrocyte membrane. J. Biol. Chem. 269:6347-6354.

21. Sims, P. J., E. M. Faioni, T. Wiedmer, and S. J. Shattil. 1988. Complement proteins C5b-9 cause release of membrane vesicles from the platelet surface that are enriched in the membrane receptor for coagulation factor $\mathrm{Va}$ and express prothrombinase activity. J. Biol. Chem. 263:18205-18212.

22. Giblin, P. A., D. J. Leahy, J. Mennone, and P. B. Kavathas. 1994. The role of charge and multiplefaces of the CD8 $\alpha / \alpha$ homodimer in binding to major histocompatibility complex class I molecules: Support for a bivalent model. Proc. Natl. Acad. Sci. USA. 91:1716-1720.
23. Funakoshi, T., R. L. Heimark, L. E. Hendrickson, B. A. McMullen, and K. Fujikawa. 1987. Human placental anticoagulant protein: Isolation and characterization. Biochemistry. 26:5572-5578.

24. Thiagarajan, P., and J. F. Tait. 1991. Collagen-induced exposure of anionic phospholipid in platelets and platelet-derived microparticles. J. Biol. Chem. 266:24302-24307.

25. Zwaal, R. F. A., P. Comfurius, and E. M. Bevers. 1992. Platelet procoagulant activity and microvesicle formation. Its putative role in hemostasis and thrombosis. Biochim. Biophys. Acta. 1180:1-8.

26. Ning, Z.-Q., and J. J. Murphy. 1993. Calcium ionophore-induced apoptosis of human B cells is preceded by the induced expression of early response genes. Eur. J. Immunol. 23:3369-3372.

27. Orrenius, S., D. J. McConkey, and P. Nicotera. 1991. Role of calcium in toxic and programmed cell death. Adv. Exp. Med. Biol. 283:419-425. 